\title{
When Statutes Collide: Potential Recovery of Own Party Adjudication Costs
}

\begin{abstract}
Purpose This research examines the potential recovery of own party adjudication costs under the Late Payment of Commercial Debts Regulations 2013.

Design/methodology/approach The interaction between The Late Payment of Commercial Debts Regulations 2013 (derived from European Directive 2011/7/EU on combating late payment in commercial transactions) and the Local Democracy, Economic Development and Construction Act 2009 including reference to case law was explored. A qualitative research framework was used to collect primary data through semi-structured interviews with adjudication experienced construction industry professionals.
\end{abstract}

Findings It was discovered that adjudicators are awarding own party costs under the Regulations but there was disagreement on the issues in both the literature and amongst the interviewees.

Research limitations/ implications A definitive judgement is awaited from the Technology and Construction Court.

Originality/ Value This paper will be of value to construction industry adjudication professionals.

Keywords adjudication costs; Local Democracy, Economic Development and Construction Act 2009; The Late Payment of Commercial Debts Regulations 2013; statutory interpretation

Paper Type Research paper 


\section{Introduction}

The aim of this research is to explore the potential interaction between two relatively new pieces of legislation namely; The Late Payment of Commercial Debts Regulations 2013 ("the Regulations") which apply to England, Wales and Northern Ireland and the Local Democracy, Economic, Development and Construction Act 2009 ("LDEDCA") which is in force in England, Wales and Scotland specifically about recovery of own party adjudication costs in construction cases.

The LDEDCA amended the Housing Grants, Construction and Regeneration Act 1996 ("the Construction Act") which applies to England, Wales and Scotland. This investigation therefore directly applies to England and Wales but may be relevant to other jurisdictions.

The Regulations are an entirely separate piece of legislation derived from European Directive 2011/7/EU on combating late payment in commercial transactions. They amend the Late Payments of Commercial Debts (Interest) Act 1998 ("the Late Payment Act") (Department for Business Innovation \& Skills, 2013)

To date there has been no test case in the Technology and Construction Courts (TCC) which draws together the provisions from both the LDEDCA and the Regulations regarding the recovery of own party adjudication costs.

The background for this research is the case law derived from the Construction Act and the LDEDCA with statutory interpretation being the specific area of interest. Much will depend upon the interpretation given to clause $5 \mathrm{~A}(2 \mathrm{~A})$ of the Late Payment Act as inserted by the Regulations:

"if the reasonable costs of the supplier in recovering the debt are not met by the fixed sum, the supplier shall also be entitled to a sum equivalent to the difference between the fixed sum and those costs."

According to Stephens (2013) "there is clash between the provisions of the LDEDCA and the provisions of the Regulations". There is a possible conflict in the statutory interpretation of section 141 of the LDEDCA which addresses "adjudication costs" and amended section 5A(2A) of Late Payment Act which entitles a supplier to its reasonable costs of recovering a debt.

Statutory interpretation is unpredictable and there is a contention that different tribunals may arrive at different answers based upon the same facts but using different precedents, interpretation and ratio decidendi. Legal realists such as Karl Llewellyn and Oliver Wendell Holmes stated that gut instinct is sometimes the real decider and rationalizing and 
reasoning follows after the decision has been made using whatever authorities are required (Leiter, 2002). Given the absence of any case law, this research aims to provide a structured commentary on the potential effects on recovery of own party adjudication costs under the Regulations.

This research therefore explores "When statutes collide: potential recovery of own party adjudication costs under the Late Payment of Commercial Debts Regulations 2013".

The relevant literature, cases and legislation are reported under the headings: statutory adjudication, recovery of adjudication costs, Late Payment of Commercial Debts Regulations 2013 and statutory interpretation. A socio-legal research style investigating the law in context was implemented (Chynoweth, 2008). A qualitative research methodology was adopted with six construction industry professionals who might have experience of recovering adjudication costs by the Regulations interviewed (Creswell, 2013). The practitioners were questioned about their understanding of the interaction between the Regulations and the LDEDCA. The responses were analysed and the conclusions reached.

\section{Statutory Adjudication}

The major tenet of the Housing Grants, Construction and Regeneration Act 1996 ("the Construction Act") was the right to statutory adjudication (Kennedy et al, 2010).

In the first Construction Act case, Macob v Morrison ${ }^{1}$ Dyson J stated:

"The intention of Parliament in enacting the Act was plain. It was to introduce a speedy mechanism for settling disputes in construction contracts on a provisional interim basis, and requiring the decisions of adjudicators to be enforced pending the final determination of disputes by arbitration, litigation or agreement.

As Lord Denning remarked in Dawnays $v$ Minter" ; "Cashflow is the life blood of the building industry."

The Construction Act was amended by Local Democracy, Economic, Development and Construction Act 2009 ("LDEDCA"). The relevant Section 141 is analysed later under the heading 3.4 Statutory recovery of adjudication costs.

Disputes are usually referred to an adjudicator nominating body (ANB) which then appoints an adjudicator from their approved listing. ANBs also

\footnotetext{
${ }^{1}$ [1999] C.L.C. 739; [1999] B.L.R. 93; (1999) 1 T.C.L.R. 113; 64 Con. L.R. 1

2 [1971] 1 W.L.R. 1205
} 
administer the training and qualifications of adjudicators who are registered with them (Kennedy et al, 2010). The main source of appointment of adjudicators remains by ANBs at $90.7 \%$. The other two means of appointment are by agreement of the parties and being named in the contract making up $7.8 \%$ and $1.6 \%$ respectively (Trushell et al, 2012). The adjudicators appointed have fluctuated over time but the two principal groups are quantity surveyors with some legal training with a growing number of lawyers. The increasing proportion of lawyers perhaps reflects that adjudication has become as much about the law regarding the procedural, natural justice and jurisdictional issues involved in adjudication than the original dispute. These professionals are followed by a group comprising civil engineers, architects and professional builders (Kennedy et al, 2010).

Atherton (2010) states that he considers adjudication has been a "tremendously successful process, facilitating quick resolution of construction disputes and revolutionising the dispute resolution process"

\section{Recovery of Adjudication Costs}

\subsection{Quantum of adjudication costs}

It is a basic tenet in litigation or arbitration that the judge or arbitrator has the power to award costs against the losing party. Atherton (2010) makes the point that the LDEDCA and predecessor Construction Act are silent as to the award of own party costs.

Costs in adjudication have remained significantly lower than arbitration or litigation (Knowles, 2012). Typical costs can range in the parameters of $£ 15,000-£ 20,000$ (Atherton, 2010). Whilst Gwiliam (2013) states that the most popular range for adjudicators' fees remains between "£2,500 to $£ 5,000$, very closely followed by the band $£ 15,001-£ 20,000$." She also states that the average fee of an own party representative is $£ 19,700$.

A party contemplating adjudication may consider that the potential non recovery of costs is a barrier to pursuing the claim. This can be exacerbated where there is an asymmetric relationship between a subcontractor and main-contractor in terms of size, turnover and access to legal resources. A disreputable main contractor may well withhold the last $£ 10,000$ in the realisation that there is no commercial incentive to pursue the amount when the own party costs are taken into account (Gwilliam, 2013).

It appears that parliament's initial expectation was that parties would represent themselves in adjudication. However, as the process has developed with the intervention of solicitors and claims consultants, costs can obviously increase especially considering that the original intent of 
the Construction Act was that the individual would represent themselves without advocacy (Knowles, 2012). It is clearly put by Agapiou (2013):

"the concept of parties being able to go to adjudication themselves was the plan at the start - however with the involvement of lawyers, this has changed the original plan. I cannot imagine it reverting back to the original concept".

The commercial reality is that claims of less than $£ 15,000$ are often untenable due to the cost that would be expended in the adjudication and therefore any award would be pyrrhic (Atherton, 2010).

\subsection{Contractual recovery of adjudication costs}

Rawley et al. (2013) state that there is no requirement for a construction contract to empower the adjudicator to award own party costs, neither does it preclude them from doing so should they so wish to do so. They go onto to state that the Scheme includes no term regarding the apportionment of legal fees of the parties and the adjudicator will only have power to award costs if both parties have agreed beforehand as part of the contract with the adjudicator prior to his commencement.Knowles (2012) states that most standard forms of contract make no provision for the adjudicator to order the payment of one party's cost by another unless a special provision is made within the contract. Ndekugri and Rycroft (2009) state similar effect and go on to add that the JCT suite does not give any party the power to award costs.

Knowles (2012) notes an exception in GC Works General conditions 1998 where "the adjudicator's decision shall state how the cost of the adjudicators fee or salary (including overheads) shall be apportioned between the parties, and whether one party is to bear the whole or part of the reasonable legal and other costs and expenses of the other, relating to the adjudication." Similarly, the RIBA SFA/99 gives the adjudicator power to apportion not only his costs but also the other party's as well.

As regards the award of costs between the parties where they have an express contractual provision to apportion own party costs, there is guiding case law. In the case of John Cothliff $v$ Allen Build ${ }^{3}$, $\mathrm{HHJ}$ Marshall Evans held that the adjudicator did possess the power to award own party costs which was requested by the referring party in the referral notice. The adjudicator considered that he had such power and ordered the respondent to pay some $70 \%$ of the referring party's costs. His rationale for this was based on sections 13(h) (right of adjudicator to issue instructions) and 16 (right to representation) of the Scheme.

${ }^{3}$ [1999] CILL 1530 
Shortly afterwards in Northern Developments (Cumbria) Ltd v J\&J Nichol ${ }^{4}$ both parties had expressly agreed to the adjudicator determining cost liability which he apportioned in accord with established Civil Procedure Rules (CPR) principles. As both parties had requested that the other would be liable to cover their winner's costs, $\mathrm{HHJ}$ Bowsher found that he had the ability to award these. One caveat was that this ability only existed due to the express request by both parties to do so. He went further to point out that the ruling in the John Cothliff case was incorrect as only one party had requested costs to be awarded in that instance.

"an adjudicator was not given any power under the Scheme for Construction Contracts (England and Wales) Regulations 1998 to award costs. However, in this instance there was an implied agreement between the parties that he should do so."

He also added that;

"provided they do not detract from the requirement of the Act and the Scheme, that parties are free to add their own terms and there is no reason why they should not expressly agree that the adjudicator should have power to order one party to pay the costs of the other"

In Court of Appeal case John Roberts Architects v Parkcare Homes (no 2) it was held that the correct interpretation of the agreement for adjudication the adjudicator's power to direct the payment of legal costs was not limited to circumstances in which he made a substantive contested decision on the dispute referred to him. Stephens (2013) puts it simply by stating that where a contract/adjudication procedure expressly permits allocation of costs, discontinuation is likely to be met with the submission that the discontinuing party pays the cost of the other.

\subsection{Potential recovery of adjudication costs as damages or in subsequent proceedings}

One further case of relevance was that of Total M\&E Services $v A B B$ Technologies ${ }^{6}$ whereby the claiming party attempted to recover his own party costs in a claim for common law damages. HHJ Wilcox held that;

"since the Act does not provide for the recovery of costs the claim is misconceived. Furthermore, this claim is put as a claim for damages for breach of contract arising out of ABB's failure to pay. Because the Statutory Scheme envisages both parties may go to Adjudication and incur costs which they cannot, under the Act

\footnotetext{
${ }^{4}$ [2000] B.L.R. 158; (2000) 2 T.C.L.R. 261

${ }^{5}$ [2005] [2006] EWCA Civ 64; [2006] [2006] B.L.R. 106

${ }^{6}$ [2002] EWHC 248 (TCC)
} 
recover from the other side, it follows that such costs cannot therefore arise as damages for breach. To permit such claim would be to subvert the statutory scheme under the Act."

The above case posed the question "to what extent should costs incurred in adjudication be recoverable in subsequent litigation?" (Gwilliam, 2013). She continues that Total $v A B B$ states that own party costs cannot be recovered, but that it could be appropriate that costs including adjudicator's costs should be recoverable in future actions in a similar vein to the costs incurred in complying with the pre-action protocol for construction and engineering disputes. Strength for this argument can be found in Fenice Investments $v$ Jerram Falkus Construction ${ }^{7}$ where the judge ruled that parties are made jointly and severally liable for such fees and that the winning party could recover the costs it had paid to the adjudicator on the default by the loser.

Gwilliam (2013) goes on to pose the question that where a party has incurred costs in an adjudication, why then should these costs not be recoverable as costs incidental to the court proceedings. She cites the example that documents prepared for the adjudication may have helped to identify critical contract terms and the substance of each party's case. Similarly, expert reports and witness testimony could be used in part or whole.

\subsection{Statutory recovery of adjudication costs}

Coulson (2011) states that section 108 of the Construction Act gives no ability for the adjudicator to award own party costs and whilst the Scheme for Construction Contracts (England and Wales) Regulations 1998 ("the Scheme") provides detailed guidance on the payment of the adjudicators' fees it is also silent on the award of costs. Furst and Ramsay (2012) argue that it is a matter of policy for the makers of adjudication rules whether adjudication costs are recoverable. The TECBAR Adjudication Rules and ICE Adjudication Procedure (1997) provide that each party should bear its own costs of the adjudication.

In Bridgeway Construction Ltd $v$ Tolent Construction $L t d^{8}$, a clause was written into a sub contract outlining that the claiming party would have to pay the respondent's share of the adjudication costs which could be commercially prohibitive to the claiming party. This term was known as a 'Tolent Clause' and was upheld by HHJ McKay who considered the term to be not incompatible with the Construction Act and indeed not unfair to either party as the onus was put on the party bringing the action. The doctrine of freedom to contract was cited as allowing the clause to stand.

\footnotetext{
${ }^{7}$ [2011] EWHC 1678 (TCC)

${ }^{8}$ [2000] (TCC) CILL662
} 
However, this case caused considerable concern to those representing sub-contractors (Riches and Dancaster, 2004).

A major aim of the LDEDCA was an attempt to correct the perceived injustice of 'Tolent clauses'. The LDEDCA applies to any contract formed after $1^{\text {st }}$ October 2011. However, in a case which preceded the LDEDCA, Yuanda $v \mathrm{Gear}^{9}$ it was held that a clause requiring a trade contractor to bear both parties' legal and expert costs if it referred a dispute to adjudication did not comply with the Construction Act (Lal, 2010). This was distinguished from the ratio in Tolent where the judge decided that it was really an issue of freedom to contract.

"The parties were free to contract as they chose and it would be unsatisfactory in legal terms for an unsuccessful party to challenge the contract on that basis."

Section 141 of the LDEDCA attempted overcome the controversial judgement in Tolent by inserting the following:-

"Adjudication costs

In the Housing Grants, Construction and Regeneration Act 1996, after section 108 insert-

108A Adjudication costs: effectiveness of provision

(1)This section applies in relation to any contractual provision made between the parties to a construction contract which concerns the allocation as between those parties of costs relating to the adjudication of a dispute arising under the construction contract.

(2)The contractual provision referred to in subsection (1) is ineffective unless-

(a)it is made in writing, is contained in the construction contract and confers power on the adjudicator to allocate his fees and expenses as between the parties, or

(b) it is made in writing after the giving of notice of intention to refer the dispute to adjudication."

There appears to be a 'tension' between the two underlined sections (above) in the LDEDCA. In the first instance it refers to costs and in the latter to the adjudicator's fees and expenses. Furst and Ramsay (2012, p.704) comment "The wording of this provision is unfortunate." Stephens

\footnotetext{
${ }^{9}$ [2010] EWHC 720 (TCC); [2011] 1 All E.R. (Comm) 550
} 
(2013) states that there might be some fertile ground here for argument in relation to the precise scope of the prohibition in relation to Tolent clauses.

Whilst the ratio in the Yuanda case appears to put a brake on the use of Tolent clauses, the new Section 108A should have resulted in a complete and absolute moratorium but instead leaves the position still far from unequivocal. Couslon (2011) states it is arguable that the decision in the Yuanda case already renders the requirement for the insertion of the new 108A clause redundant. He goes onto say that these are "curious provisions". He postulates that whilst the intent may have been to deal with the Tolent clause issue, he considers this to have been closed out in Yuanda. He questions the efficacy of the provisions in their current format and suggests that only legal authority will iron out how they are supposed to be interpreted. Stephens (2013) also questions the merit of the above section stating that it would appear to be a "little vague" and perhaps unnecessary after the Yuanda verdict.

\section{Late Payment of Commercial Debts Regulations 2013}

The UK was one of the first European Union ("EU") countries to implement the European Directive 2011/7EU ("the Directive") with the Late Payment of Commercial Debts Regulations 2013 ("the Regulations"). The Late Payment of Commercial Debts (Interest) Act 1998 ("the Late Payment

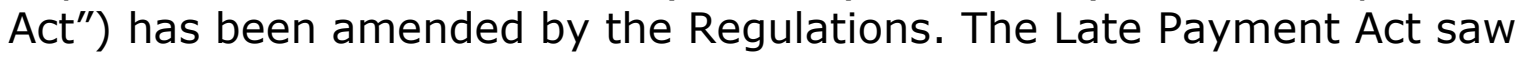
the implementation in stages between 1998 and 2002 of a remedy to secure statutory interest which accrues to late debt payments.

The Late Payment Act includes fixed sums for the costs of recovery. These are $£ 40$ for debts less than $£ 1,000 ; £ 70$ for debts less than $£ 10,000$ and for debts exceeding $£ 10,000$ a sum of $£ 100$ is claimable.

However, the change of most interest to the construction industry with particular emphasis on adjudication can be found in the amended Section 5A of the Late Payment Act. This applies any contract signed or agreed after $16^{\text {th }}$ March 2013.

- "3.- (1) Section 5Aof the Late payment of Commercial Debts (interest) Act 1998 (b) (compensation arising out of late payment) shall be amended as follows:

- (2) after subsection (2) insert -

- (2a) if the reasonable costs of the supplier in recovering the debt are not met by the fixed sum, the supplier shall also be entitled to a 
sum equivalent to the difference between the fixed sum and those costs."

Stephens (2013) asserts that it is clear that the Regulations mean recoverable expenses should include the cost of instructing solicitors or employing a debt collection agency which she views to be firmly within the allowable costs referred to in $5 \mathrm{~A}(2 \mathrm{~A})$. However, she points out that this is a remedy only available to the supplier and not the purchaser if the Late Payment Act is invoked.

This argument is supported by Article 6.3 "Compensation for recovery costs" of the Directive which states:

"The creditor shall, in addition to the fixed sum referred to in paragraph 1 , be entitled to obtain reasonable compensation from the debtor for any recovery costs exceeding that fixed sum and incurred due to the debtor's late payment. This could include expenses incurred, inter alia, in instructing a lawyer or employing a debt collection agency."

This results in a possible conflict in the law between section 141 of the LDEDCA which addresses "adjudication costs" and amended section $5 A(2 A)$ of Late Payment Act which entitles a supplier to its reasonable costs of recovering a debt.

\section{Statutory Interpretation}

In Bell's (1986) review of Bennion's Statutory interpretation, he states that a new statute is not an isolated act but rightly seen as having to fit into a network of rules and values which have to be adjusted to make room for it. He goes onto to expound that that there is no one single rule for interpretation but:

"one thousand and one interpretative criteria that the reader must figuratively weigh and balance."

He goes on to state that perhaps the political side of statutory interpretation actively involves the judiciary being responsible for tidying up the inaccuracies of the legal draftsmen and that really then the interpretation of the judge can come down to assessing the political intent behind any statute and thus is a matter of public policy.

There exist four prime rules in the doctrine of interpreting statutes, namely; literal, golden, mischief and purposive. There are also permitted a number of intrinsic and extrinsic aides to which a judge may refer including access to Hansard (which has been limited by Wilson $v$ 
Secretary of State for Industry ${ }^{10}$ ). Reference may also be made to the Interpretation Act 1978.

The Regulations stem from Europe and EU law supersedes UK law as illustrated in R. $v$ Secretary of State for Transport Ex p. Factortame Ltd $(\text { No.2 })^{11}$. This supports the argument that the Regulations should take precedence when "Statues Collide". However, according to Cross et al (1995), where statutes are at odds on the same subject 'pari materia' a later act will state that it is to be read as one with earlier legislation, even though this might result in incongruous decisions. In Pepper (Inspector of Taxes) $v$ Hart $^{12}$ it was stated that the courts now give effect to the purpose of the act and this is placed above the literal approach of interpretation. Cross et al (1995) go on to state that the courts attempt to represent a compromise between the legal certainty and the will of parliament.

The Construction Act and the LDEDCA were introduced to enable prompt cash flow for parties in dispute in the construction industry. The Construction Act was silent on awarding of own party costs in adjudication but, there is now a body of case law on this issue. Despite the LDEDCA, there remains uncertainty about "Tolent" clauses. There is a potential inconsistency between the Regulations and the LDEDCA with regarding to costs which may be claimable as being "reasonable". Section 141 of the LDEDCA addresses "adjudication costs" whereas amended section 5A(2A) of Late Payment Act entitles a supplier to its reasonable costs of recovering a debt.

The literature review has highlighted the following themes for research:

- Experience of the LDEDCA and the Late Payment Act

- Interpretation of Section 108A of the LDEDCA

- Recovery of reasonable costs under the Regulations

- The "clash" between the Regulations and the LDEDCA

- Should an adjudicator be given the power to award costs under the Regulations

- Anticipated effects of a successful test case on the recovery of reasonable own party adjudication costs under the Regulations

The next section explains the research methodology adopted.

\footnotetext{
${ }^{10}$ [2003] UKHL 40; [2004] 1 A.C. 816; [2003] 3 W.L.R. 568; [2003] 4 All E.R. 97

${ }^{11}$ [1991] 1 A.C. 603; [1990] 3 W.L.R. 818; [1991] 1 All E.R. 70

${ }^{12}$ [1993] A.C. 593; [1992] 3 W.L.R. 1032; [1993] 1 All E.R. 42
} 


\section{Methodology}

Positivism and interpretivism were considered and the interpretive paradigm selected as it can be argued that reality is constructed by the individuals involved (Fellow and Liu, 2008). A socio-legal research style investigating the law in context was implemented (Chynoweth, 2008).

Qualitative research methodology was used as this would best reflect the views of practitioners within the construction industry, who may be considering recovery of adjudication costs through the Regulations (Cresswell, 2013). In this study, the authors sought to discover the understanding of construction practitioners of interaction between the Regulations and the LDEDCA.

Silverman (2006) recognizes four distinct methodologies for qualitative research: observation; analysing texts and documents; interviews and focus groups; and audio and video recording. The central method for the research was structured interviews. A pilot interview was undertaken with the questions refined afterwards.

The researchers attended several Society of Construction Law meetings to identify potential interviewees. In addition, some cold calling was employed which proved very successful. The participants selected were experienced professionals able to provide an in-depth account of how the Regulations and the LDEDCA apply to their current practice. Introductory letters and follow up correspondence as recommended (Creswell, 2013) were sent. The research sample consists of 6 participants:

- Expert witness and adjudicator - EXPWIT/ADJ

- Barrister - BAR

- Arbitrator / adjudicator - ADJ/ARB

- Construction solicitor - SOL

- Construction claims consultant - CC

- Arbitrator - ADJ

Tape recording and transcribing of interviews was fundamental (Silverman, 2006). A data analysis framework which contained transcribed and coded data was created to support critical analysis of the research data (Babbie, 2001). The data validation strategy included member checking and audit trail (Silverman, 2006).

The participants are anonymous and the research was approved and conducted in accordance with university research ethical procedures. 


\section{Data Analysis: Results and Discussion}

The aim of this research was to fill the knowledge gap which exists as to whether own party costs can be claimed and awarded in adjudications as "reasonable costs" under the Regulations. A discussion of the opinions expressed by the interviewees follows.

\subsection{Professional qualifications and experience}

All the interviewees were highly qualified and experienced professionals.

Table 1: Interviewees' professional qualifications and experience

\begin{tabular}{|c|c|c|}
\hline Interviewee & Profession & \begin{tabular}{|l|} 
Experience \\
\end{tabular} \\
\hline $\begin{array}{l}\text { EXPWIT/ADJ - Expert } \\
\text { witness/adjudicator }\end{array}$ & $\begin{array}{l}\text { Chartered quantity } \\
\text { surveyor }\end{array}$ & $\begin{array}{l}\text { Expert witness, } \\
\text { construction } \\
\text { adjudicator and claims } \\
\text { consultant }\end{array}$ \\
\hline BAR - Barrister & $\begin{array}{l}\text { Chartered civil } \\
\text { engineer and barrister }\end{array}$ & $\begin{array}{l}\text { Dispute resolution as } \\
\text { an advocate and } \\
\text { adjudicator on the } \\
\text { RICS panel }\end{array}$ \\
\hline $\begin{array}{l}\text { ADJ/ARB - } \\
\text { Adjudicator/Arbitrator }\end{array}$ & $\begin{array}{l}\text { Chartered quantity } \\
\text { surveyor, chartered } \\
\text { arbitrator and } \\
\text { adjudicator }\end{array}$ & $\begin{array}{l}\text { Expert witness based } \\
\text { in the UK for the last } \\
13 \text { years previously } \\
\text { overseas in Hong } \\
\text { Kong, Africa and the } \\
\text { Middle East }\end{array}$ \\
\hline SOL - Solicitor & Solicitor & $\begin{array}{l}\text { Specialised in } \\
\text { construction law for } \\
\text { over } 15 \text { years }\end{array}$ \\
\hline CC - Claims consultant & $\begin{array}{l}\text { Quantity surveyor with } \\
\text { a law degree }\end{array}$ & Claims consultant \\
\hline ADJ - Adjudicator & $\begin{array}{l}\text { Chartered Arbitrator } \\
\text { and adjudicator }\end{array}$ & $\begin{array}{l}\text { Very experienced in } \\
\text { construction law } \\
\text { including over } 300 \\
\text { adjudications }\end{array}$ \\
\hline
\end{tabular}

\subsection{Experience of the LDEDCA and the Late Payment Act}

All of the interviewees have some experience of the issues. Three of the interviewees have expressed that they have direct involvement where the Regulations have been used to claim $8 \%$ interest and also reasonable adjudication own party costs. 
BAR said that he was very familiar with the Late Payment Act with regard to reasonable costs, as an adjudicator and as a representative. When acting as a representative everyone tends to claim the $8 \%$ interest. As an adjudicator he has had two instances of this arising and claiming this interest, the fixed costs and additional costs and he has awarded them as allowable.

ADJ stated "I have experience of the two acts and their crossover in that the various parties in adjudication these days claim their costs of adjudication pursuant to the Late Payment Act." By contrast, ADJ/ARB explained "As regards the late payment regulations ..you can claim your reasonable costs in pursuing a debt. I know that both acts have a crossover but I have yet to be involved in an adjudication whereby a party has claimed these costs under the regulations."

\subsection{Section 108A of the LDEDCA}

The wide range of opinions reflects the literature. All parties agreed that a test case would be timely to quench the debate.

EXPWIT/ADJ stated that he considered the situation was clearer before the LDEDCA. He explained that as an adjudicator if a provision included the allocation of costs and the allocation of his fees and expenses he would listen to an argument that he had the power as regards both.

ADJ/ARB stated that "I think that a judge would take a purposive approach to interpreting the legislation and statutes and when they look at this they will see that the mischief which the act intended to outlaw was a situation where a referring party would have to pay the legal costs and adjudicator's costs of the responding party even if they won their case. "SOL argued the right to costs inferred by the Regulations is implied into the contract by statute. He assumed that this is the judgement that the court would apply.

ADJ concluded "I agree there is a problem and this problem was brought to the attention of the legislators by various construction groups but no changes were made. This is an on-going problem for the industry."

\subsection{The Regulations - reasonable costs}

BAR stated that if a person looks into the EU guidance notes it mentions additional costs, legal fees and debt collection fees and also court fees. He thought that it is very clear what they were trying to enact with this 
legislation. He further considered that when the Late Payment Act was enacted there were some certain exempt contracts to which it does not apply and maybe this should have been looked at prior to the amendments in 2013. There was the opportunity to say construction contracts could be exempt from this act because adjudication is already a quick fire solution and parties should not have to cover other party costs. He felt that the Late Payment Act is aimed towards subcontractors. They do not have a lot of money to fight big contractors who are not afraid of spending big money. BAR said the first case that comes along might be for relatively small money and this could be settled there and then, alternatively this could go up to the Court of Appeal very quickly to get some certainty. BAR concluded "Well somebody has got to make a view and I think this should be a job for the judge. You have hit the nail on the head when you talk about statutes collide!"

ADJ/ARB stated that he considered that the LDEDCA is a statutory piece of primary legislation whereas he feels the Regulations are a piece of delegated legislation albeit from the EU. He thought that the LDEDCA would take primacy over the Regulations and that when the judges come to look at the situation they will take a purposive approach with the mischief and read it the way that adjudication costs should not be allowable under the Regulations. The researcher probed that after the Factortame cases, European law prevails against English law? ADJ/ARB responded by stating that it is his understanding that wherever there is a conflict the judges should at least attempt to make the acts work together but if they cannot do so then the European legislation should prevail. SOL stated that his starting point on this is that the legal draftsman had to give effect to the European Directive. He considered that The Latham report was the genesis for both the Construction Act and the LDEDCA and that European draftsman would have very little knowledge of these two acts. The researcher asked would it be a good idea if the Late Payment Act exempted some types of contract like domestic contracts are exempt in the Construction Act? SOL stated that it would have been arguable that the Directive had not been implemented properly and a sizeable sector of the economy would then not have access to this remedy which would be inequitable. SOL stated thatthe LDEDCA is silent upon the award of costs and the courts have decided that parties can allocate the award of costs if they so wish. He argued that the fact is that the Regulations now imply this award of costs in certain circumstances. "The problem is that this only bites where it is a case of a supplier pursuing a debt." He did not see a clash between the two acts.

CC stated that coincidently he had been involved in a case recently that hit on this very point. In this case he had claimed on behalf of a client for "reasonable costs" and they were awarded them by an eminent adjudicator. CC considered that entire subject is "up for grabs" at the moment and the industry needs to get a judgement for certainty. CC 
added that in this case the adjudicator said that there was not a conflict because the LDEDCA is silent on costs but in the Late Payment Act it is the will of parliament to allow someone to claim the costs. "It should be noted as well that this is a one way street as regards claiming a debt in that only the party bringing the action can claim his costs not the other way around."

CC added that he had spoken to a senior QC on this matter and he suggested that if you have an apparent clash between two pieces of legislation then whoever drafted the latter piece of legislation is presumed to have perfect knowledge 'Pari materia' of the proceeding pieces of legislation and if he intended this not to apply to construction then they would have said so.

ADJ stated that one contention at the moment is that the Late Payment Act introduces an implied term into the contract; this is barred by S.108A of the LDEDCA, and therefore, such costs are not recoverable. He did not consider then that these costs would be allowed by a court.

\section{5 'Clash' between the Regulations and the LDEDCA}

There appears to be unanimity between all of the contributors that interaction between the Regulations and the LDEDCA is more about serendipity than any intention. The origin of the Regulations from an EU directive gives serious weight to this contention.

EXPWIT/ADJ interpreted it that the Regulations were put into legislation in a hurry in response to a European Directive. Although he considered that perhaps lawyers who resented the introduction of adjudication and the default position of costs not being awarded will welcome it as a disincentive to adjudication making other methods of dispute resolution more attractive.ADJ/ARB thought that "The drafters were people based in Brussels and I do not think that they were particularly aware of adjudication in the UK because they have a civil law system as opposed to common law which is completely at odds with the UK system. Sometimes I feel they are not really in touch with real world at all!"

\section{6 Should an adjudicator should be given the power to award costs under the Regulations.}

There is a wide range of opinions on this issue. EXPWIT/ADJ, ADJ/ARB, $C C$ and $A D J$ disagree that an adjudicator should be given the power to award costs, whereas BAR and SOL consider that it would be a positive for the industry.

EXPWIT/ADJ put it succinctly "No, but that will be argued to be its effect!" 
$A D J / A R B$ outlined that the main purpose of adjudication was to help small contractors pursue debts whereby they would not have to worry about legal costs. He felt that if the adjudicator suddenly has the power to award costs then it will put more people off of adjudication and it would do a "great harm!" to the industry.

CC stated "Generally No!" and added that the threat of having to take the costs of the other team would be prohibitive and as one judge put it a "fetter on the right to adjudication". ADJ said "No - one of the major advantages of adjudication is that there is no recovery of the parties' costs. This has the effect that the parties keep their costs to the minimum unless they contract for it together or agree to it prior to the adjudicator being appointed."

BAR stated that the answer for him was yes because he agreed with this as public policy. However, he continued that he has a case before him now with very competent solicitors and they have not claimed for the interest or the other costs which he sees not as any oversight. He has seen it a few times now and it is not unusual. SOL argued that he would not hesitate to include a claim under the Late Payment Act if he were acting as an advocate. He said that he did not really think that there is an inconsistency between the acts.

\subsection{Anticipated effects of a successful test case on the recovery of reasonable own party adjudication costs under the Regulations}

EXPWIT/ADJ, BAR, SOL and CC all identified that they saw this as a one sided risk benefitting the referring party. But CC went further by stating that he considered this to be just and fair under the circumstances. SOL stated that he saw it as "Almost a reversal of the Tolent problem".

EXPWIT/ADJ considered that this should be a benefit to referring parties who are claiming from the payee. However, he thought disputes would more likely to be settled by a payer with the threat of adjudication. He added that the benefit of adjudication as a low cost supposedly temporary fix is likely to be lost.SOL said that only one party is entitled to the costs and not the other. "It will be an upstream process. Almost a reversal of the Tolent problem that we were talking about." CC thought that it would not be a disincentive. "The fact that the money can only flow one way means that if a sum is indisputably due then for subcontractor chasing a retention figure or the last payment due under an interim he has nothing really to lose because the chances are he will be able to reclaim his own party costs as well." 
BAR stated the award of costs where statutory interest might apply would then be one-sided in that only the referring party who is chasing the debt can claim costs. The claimant would not have to suffer the responding party's costs if he loses. BAR considered this to be one of the down falls of the process. He stated that if only the referring party can get its costs then it might mean that a lot more people will chase the money. He advanced that it will probably mean that there will be a lot more settlement of interim payments. "I think that the award of party costs will change the landscape with less adjudications."

ADJ/ARB stated succinctly that he thought that this would be bad thing for smaller companies and it is not economically viable.

\section{8 Final Comments}

BAR stated that he had an adjudication recently which was distinguished by a barrister who said that this would apply in court proceedings and arbitrations but not in adjudication. BAR explained that this is the main item that all practitioners want to know the answer to at the moment. "The answer to this question is actually worth money!"

$A D J / A R B$ said this is something that is of great interest to adjudicators in the UK and obviously guidance from the courts maybe from someone like Akenhead or Coulson would be welcome as soon as possible. He was aware of adjudicators and claims consultants who are really pushing the award of costs via the Regulations. SOL said that he thinks that the Regulations dictate that an employer will have to pay costs to the supplier if he is late with his payment to him. It is something that will be interesting in negotiations as well as in adjudications.

$C C$ and $A D J$ both stated that the researcher should keep abreast of this situation as it was moving very quickly and expected there to be a resolution of this issue at some stage in the near future.

All of the gentlemen interviewed expressed an interest in receiving a copy of the completed research.

\section{9 Discussion}

In the absence of relevant case law, definitive answers cannot be expected. Nevertheless, despite the small sample size, a snapshot of current practice and concern has been revealed. The interviewees were commendably knowledgeable about the issues. 
It seems that suppliers should be encouraged to demand their costs in adjudication and their clients resist payment until there is a judicial binding precedent. More widespread practice could be explored by a larger sample perhaps on a quantitative basis.

\section{Conclusions}

The Construction Act was silent on awarding of own party costs. However, there is now a rich body of case law where parties have contracted about costs prior to adjudication.

There are two perceived problems with the Construction Act and the LDEDCA. The first being "Tolent" clauses and the second; the purposed mechanism within the LDEDCA to resolve the "Tolent" issue. However, this issue remains uncertain. There is a potential inconsistency between the Regulations and the LDEDCA with regarding to costs which may be claimable as being "reasonable" under the amended Late Payment Act. Resolution is likely to result from judicial interpretation when a test case is eventually heard in the Technology and Construction Court.

In addition, the Government undertook to review the application of the LDEDCA three years following its implementation; due in the autumn of 2014 (Sinden et al 2012). However, this report has yet to be published. The issues identified in this research should be raised in any consultation and may result in clarification and reform of the legislation.

Primary research from professionals within the field of construction law was undertaken by semi-structured interviews. As expected there were a diverse range of opinions. The only issue on which the contributors were unanimous was that the apparent interaction between the LDEDCA and the Regulations does not appear to be intended.

Nevertheless, there is very persuasive evidence from the interviewees that own party costs could be awardable in adjudication. In particular, claims consultant CC had been involved in an adjudication in which a prominent adjudicator had awarded costs under the Regulations and he stated that it was mere luck that this was not put before a tribunal for judicial scrutiny.

Perhaps the most obvious barrier to any potential claimant will be that the remedy is only available to suppliers. Stephens (2013) and Coulson (2011) both identified this issue. Several of the interviewees identified this problem indeed, one of the gentlemen went as far as to state that he saw it "Almost a reversal of the Tolent problem."

In the absence of judicial precedent, there is no authoritative guidance. However, from the literature review and the primary research undertaken 
there appears to be a very strong case that own party adjudication costs would be recoverable as "reasonable costs" and as evidenced in a recent adjudication. However, one adjudication decision does not set a precedent. Until a Technology and Construction Court ruling, there will be no certainty. "Up for grabs" was how one commentator put it.

The answer to the question proposal posed "When Statutes Collide: Potential Recovery of Adjudication Costs Under the Late Payment of Commercial Debts Regulations 2013", will depend upon statutory interpretation by the judiciary of clause $5 \mathrm{~A}(2 \mathrm{~A})$ of the Late Payment Act:

- (2A) if the reasonable costs of the supplier in recovering the debt are not met by the fixed sum, the supplier shall also be entitled to a sum equivalent to the difference between the fixed sum and those costs."

A Technology and Construction Court judgment is eagerly awaited.

\section{References}

Agapiou, A. (2013), "UK Construction Participants Experience of Adjudication" Management and Procurement Law, Vol. 166 Issue MP3.

Atherton, M. (2010), "Adjudication at the Crossroads: The Construction Act - One Size fits All?", Construction Law Journal, Vol.26 No.4, pp.242346

Babbie, E. (1990), Survey Research Methods, Wadsworth Publishing Company, Belmont

Bell, J. (1986), "Bennion's 'Statutory Interpretation'", Oxford Journal of Legal Studies, Vol.6 Issue 2, pp. 288-298

Bridgeway Construction Ltd v Tolent Construction Ltd [2000] (TCC) CILL662

Chynoweth, P. (2008) Legal research. in Knight, A. and Ruddock, L. (eds.) Advanced Research Methods in the Build Environment. Oxford: WileyBlackwell, pp. 28-38.

Coulson, P. (2011), Coulson on Construction Adjudication, Oxford University Press, Oxford

Creswell, J.W, (2013), Research Design: Qualitative, Quantitative and Mixed Methods Approaches, Sage Publications, London 
Cross, R., Bell, J. and George, E. (1995), Statutory Interpretation, Oxford University Press, Oxford

Dawnays Ltd. v. F.G. Minter Ltd. and Trollope \& Colls Ltd [1971] 1 W.L.R. 1205

Department for Business Innovation \& Skills (2013) "A Users Guide to the Recast Late Payment Directive" available at:

http://webarchive.nationalarchives.gov.uk/20130730101538/https://www gov.uk/government/uploads/system/uploads/attachment data/file/1381 29/bis-13-705-a-users-guide-to-the-recast-late-payment-directive.pdf (Accessed 26 November 2014)

Directive $2011 / 7 /$ EU on combating late payment in commercial transactions

Fenice Investments Inc $v$ Jerram Falkus Construction Limited (No.

4) [2011] EWHC 1678 (TCC)

Fellows, R. and Liu, A. (2008), Research Methods for Construction, WileyBlackwell, Oxford

Furst, S. and Ramsay, V. (2012) Keating on construction contracts, Sweet \& Maxwell, London

Gwilliam R, (2013), Protocoligorically Correct? Recovering Adjudication Costs under the Pre-Action Protocol, Construction Law Journal Volume 29 Issue 7, pp. 466-479

Housing Grants, Construction and Regeneration Act 1996 c.53

Interpretation Act 1978 c.30

John Cothliff Ltd v Allen Build Ltd [1999] CILL 1530

John Roberts Architects Ltd v Parkcare Homes (No 2) Ltd [2005] [2006] EWCA Civ 64; [2006] [2006] B.L.R. 106

Kennedy P, Milligan J, Cattanach L, and McCluskey E (2011), "The Development of Statutory Adjudication in the UK and its Relationship with Construction Workload" School of the Built and Natural Environment, Glasgow Caledonian University available at:

http://www.gcu.ac.uk/media/gcalwebv2/ebe/content/COBRA\%20Confere nce\%20Paper\%202010.pdf (accessed 26 November 2014) 
Knowles, R. (2012), 200 Contractual Problems and their Solutions, WileyBlackwell, Chichester.

Lal, H. (2010), An attempt to unfetter adjudication", Estates Gazette, Issue 404 p. 85

Late Payment of Commercial Debts (Interest) Act 1998 c.20

Leiter B (2002), "American Legal Realism", University of Texas Law School, Public Law Research Paper No.42 available at:

http://papers.ssrn.com/sol3/papers.cfm?abstract id=339562 (accessed 26 November 2014)

Local Democracy, Economic Development and Construction Act 2009 c.20

Macob Civil Engineering Ltd v. Morrison Construction Ltd [1999] C.L.C. 739; [1999] B.L.R. 93; (1999) 1 T.C.L.R. 113; 64 Con. L.R. 1

Ndekugri, I. and Rycroft, M. (2009), The JCT 05 standard building contract: law and administration, Butterworth-Heinemann, London.

Northern Developments (Cumbria) Ltd v J\&J Nichol [2000] B.L.R. 158; (2000) 2 T.C.L.R. 261

Pepper (Inspector of Taxes) v Hart [1993] A.C. 593; [1992] 3 W.L.R. 1032; [1993] 1 All E.R. 42

$R \vee$ Secretary of State for Transport ex p. Factortame 1990 [1991] 1 A.C. 603; [1990] 3 W.L.R. 818; [1991] 1 All E.R. 70

Rawley, D., Williams, K., Martinez, M. and Land P, (2013), Construction Adjudication and Payments Handbook, Oxford University Press, Oxford.

Riches, J. and Dancaster, C. (2004) Construction Adjudication, Blackwell Publishing, Oxford

Silverman, D. (2005), Doing Qualitative Research (2 ${ }^{\text {nd }}$ edition), Sage, Thousand Oaks.

Sinden, G., Mason, J., Proverbs, D. \& Booth, C. 2012, "The new Construction Act: views and perceptions of construction industry stakeholders", Structural Survey, vol. 30, no. 4, pp. 333-343

Stephens, J. (2013), "Recovery of Costs in Adjudication - permissible enforceable?" Adjudication Society Midlands Region on 8 October 2013

The Late Payment of Commercial Debts Regulations 2013 No.395 
Total M\&E Services v ABB Technologies [2002] EWHC 248 (TCC)

Trushell, I., Milligan, J. and Cattanach, L., (2012) "Adjudication Report No 12", Adjudicating Reporting Centre, Glasgow Caledonian University available at:

http://www.gcu.ac.uk/media/gcalwebv2/ebe/content/Adjudication\%20Re port\%2012\%20-\%200ctober\%202012.pdf (accessed 26 November 2014)

Wilson - $v$ - Secretary of State for Trade and Industry [2003] UKHL 40; [2004] 1 A.C. 816; [2003] 3 W.L.R. 568; [2003] 4 All E.R. 97

Yuanda (UK) Co Ltd v WW Gear Construction Ltd [2010] EWHC 720 (TCC); [2011] 1 All E.R. (Comm) 550 